\title{
Correction to: Accessibility and Gamification Applied to Cognitive Training and Memory Improvement
}

Ana Carol Pontes de Franca, Arcângelo dos Santos Safanelli, Léia Mayer Eyng, Rodrigo Diego Oliveira, Vânia Ribas Ulbricht, and Villma Villarouco

Correction to: Chapter "Accessibility and Gamification Applied to Cognitive Training and Memory Improvement" in: Á. Rocha et al. (Eds.): Information Technology and Systems, AISC 918, https://doi.org/10.1007/978-3-030-11890-7_43

In the original version of this chapter, the following correction has been incorporated: Rodrigo Diogo Oliveira has been changed to Rodrigo Diego Oliveira. 